\title{
BRILJANTE MISLUKKINGEN
}

door

MARIAN ADRIAANSEN

Gezocht: briljante

implementatie-

mislukkingen in de zorg.

Ze kunnen de branche

iets leren en een

inspiratiebron zijn.
MPLEMENTATIE VAN NIEUWE

methodieken in de gezondheidszorg

gaat niet vanzelf. Vaak duurt het jaren voordat standaarden en richtlijnen daadwerkelijk worden gebruikt. En soms mislukt implementatie van interventies die vooraf veelbelovend en goed doordacht leken. Toch kunnen de ervaringen bij dit soort trajecten waardevol zijn. Tijdschriften zijn vaak niet geïnteresseerd in dergelijke resultaten, ze richten zich vooral op succesvolle bevindingen. Het Instituut voor Briljante Mislukkingen (www.brimis.nl) is er om meer aandacht te genereren voor wat we van ogenschijnlijk mislukte implementatieprojecten kunnen leren. Een briljante mislukking is 'een goed voorbereide poging om iets te realiseren, die een andere uitkomst heeft dan gepland'. Mislukkingen kunnen vaak voor nieuwe inzichten en dus vooruitgang zorgen. Het innovatieklimaat wordt bevorderd door vergroten van het lerend vermogen, dat zowel voor, tijdens als na de innovatie kan plaatsvinden.

\section{Verkeerde portemonnee}

Het instituut probeert leerervaringen op te halen en patronen te herkennen bij mislukte projecten. De patronen worden archetypen genoemd; er worden er 16 onderscheiden. Ze kunnen worden gekoppeld aan de bij het instituut ingediende projecten en staan op de website. Archetypen die bijvoorbeeld regelmatig voorkomen in de gezondheidszorg: de lege plek aan tafel, de verkeerde portemonnee en de rechterhersenhelft. Bij 'de lege plek aan tafel' zijn niet alle relevante partijen bij het project betrokken. Als een partij ontbreekt bij de implementatie, is de kans groot dat deze het nut van de innovatie niet ziet of zich buitengesloten voelt, waardoor hij niet wil meewerken. De 'verkeerde portemonnee' gaat over het voordeel voor de ene partij dat een nadeel voor de andere kan zijn. Een voorbeeld: technologie wordt door de gemeente via de Wet maatschappelijke ondersteuning gefinancierd en leidt tot uitstel van verpleeghuisopname. Er hoeft minder een beroep gedaan te worden op financiering via de Wet langdurige zorg. Dit is een wettelijke volksverzekering, waarvoor via de loonbelasting een inkomensafhankelijke premie wordt betaald. Gemeenten worden dus geconfronteerd met hogere Wmo-uitgaven, maar krijgen geen extra financiering. Daarom willen ze zelden technologie vergoeden, zodat ouderen toch moeten worden opgenomen in het verpleeghuis. 'De rechterhersenhelff' is van invloed, omdat niet alle beslissingen rationeel zijn. Dat speelde een rol toen tijdens de Covid-19-crisis stewardessen zich konden laten omscholen tot verpleegkundige, omdat de beroepen veel overeenkomsten leken te hebben. Van de 10.000 stewardessen maakten er 35 de overstap... De anderen vonden hun levensritme niet te vergelijken met dat van een verpleegkundige. Ook kwalificeerden ze zorg voor ouderen als minder afstandelijk dan hun eigen dienstverlening. Die afstandelijkheid waardeerden ze zeer.

\section{Uitnodiging}

In plaats van niet-gelukte implementatieprojecten te verdoezelen, zouden we ze onder de aandacht moeten brengen om ervan te leren. Daarom worden projectleiders uitgenodigd hun mislukte project te publiceren op de website van het instituut. Anderen kunnen er inspiratie uit halen. Jaarlijks worden de Briljante Mislukkingen Awards Zorg uitgereikt voor projecten die goed doordacht zijn en een grote impact zouden kunnen hebben, maar niet zijn geslaagd. De lessen uit het project moeten breed toepasbaar zijn. 